\title{
The Relationship Between ABO and Rh Blood Groups with Acute Lymphoblastic Leukemia
}

\section{ABO ve Rh Kan Grupları ile Akut Lenfoblastik Lösemi Arasındaki İlişki}

\author{
Semih Başcı ${ }^{1}$, Tuğçe Nur Yiğenoğlu ${ }^{1}$, Derya Şahin ${ }^{1}$, Özcan Saygılı ${ }^{2}$, Mehmet Bakırtaş ${ }^{1}$, Bahar Uncu \\ Ulu $^{1}$, Tahir Darçın' ${ }^{1}$, Alparslan Merdin ${ }^{1}$, Dicle İskender ${ }^{1}$, Mehmet Sinan Dal ${ }^{1}$, Merih Kızıl Çakar ${ }^{1}$, Fevzi \\ Altuntas $^{1}$ \\ ${ }^{1}$ Hematoloji ve Kemik İliği Nakil Merkezi, Dr. Abdurrahman Yurtaslan Ankara Onkoloji Eğitim Ve Araştırma \\ Hastanesi \\ ${ }^{2}$ İç Hastalıkları Kliniği, Dr. Abdurrahman Yurtaslan Ankara Onkoloji Eğitim Ve Araştırma Hastanesi
}

\section{ÖZET}

GíRIŞ ve AMAÇ: Akut lenfoblastik lösemi (ALL), hematopoietik lenfoid öncüllerinden kaynaklanan blastların anormal çoğalmasından kaynaklanır. ALL, pediatrik lösemi vakalarının \% 75'ini oluşturur ve yetişkinlerde 1.28/100.000 insidansı vardır. ALL etiyolojisi hala tartı̧̧ma konusudur. Bazı çalışmalarda, ABO kan gruplarının kardiyovasküler, onkolojik ve diğer hastalıkların gelişimininde rol oynadığı gösterilmiştir. Bu çalışmada ALL ile $A B O$ ve Rh kan grupları arasındaki ilişkileri araştırmayı amaçladık.

YÖNTEM ve GEREÇLER: Merkezimizde Şubat 2014 ile Nisan 2020 arasında tedavi edilen 124 ALL hastas1 retrospektif olarak incelendi. Sağliklı trombosit donörlerinin yaş, cinsiyet ve kan grubu verileri kontrol grubu olarak kullanıldı.

BULGULAR: Hem erkek hem de kadınlarda en yaygın kan grubu A Rh + olmasına rağmen, kontrol grubu ve ALL hastaları arasında $\mathrm{ABO}$ kan grubu dağılımı ve Rh pozitifliği açısından istatistiksel olarak anlamlı bir fark bulamadık. Her iki grup da cinsiyete göre alt gruplandırıldığında, gruplar arasında $\mathrm{ABO}$ ve $\mathrm{Rh}$ dağılımı açısından farkl11lk izlenmemiştir.

TARTIŞMA ve SONUÇ: ALL ve kan grupları arasındaki ilişkiye dair çok az çalışma vardır. Çalışmamız ALL kan grubu ile sağlıklı insanlar arasında kan grupları sıklığının benzer olduğunu desteklemektedir. Daha büyük hasta popülasyonları ile ileri çalışmalara ihtiyaç vardır.

Anahtar Kelimeler: Akut lenfoblastik lösemi, ABO kan grubu, Rh grubu

\begin{abstract}
INTRODUCTION: Acute lymphoblastic leukemia (ALL) is caused by abnormal proliferation of blasts originated from hematopoietic lymphoid precursors. ALL constitutes $75 \%$ of pediatric leukemia cases and has an incidence of 1.28/100.000 in adults. The etiology of ALL is a still matter of debate. In some studies, ABO blood groups were shown playing a role in development of cardiovascular, oncologic, and other diseases. In this study, we aimed to investigate relationship with ALL and $\mathrm{ABO}$ and Rh blood groups.

METHODS: 124 ALL patients treated at our center between February 2014 and April 2020 were retrospectively studied. The data of age, gender and blood group of healthy thrombocyte donors were used as the control group. RESULTS: Although the most common blood group was A Rh+ among both males and females, we did not find a statistically significant difference between control group and ALL patients regarding ABO blood group distribution and $\mathrm{Rh}$ positivity. When both groups were sub-grouped according to gender, they did not differ between $\mathrm{ABO}$ and Rh distribution.

DISCUSSION AND CONCLUSION: There are few studies about the relationship between ALL and blood group types. Our study suggests blood group frequency might be similar among ALL patients with healthy individuals. Further studies with larger patient populations are needed.
\end{abstract}

Keywords: Acute lymphoblastic leukemia, $\mathrm{ABO}$ blood groups, Rh group

\section{INTRODUCTION}

Acute lymphoblastic leukemia (ALL) is a hematological malignancy characterized by abnormal proliferation of blasts caused by hematopoietic lymphoid precursors. It becomes symptomatic in a short time due to its aggressive nature [1,2]. ALL is most frequently seen in children. It constitutes $75 \%$ of pediatric leukemia cases [3]. In adults, ALL has an incidence of $1.28 / 100.000$, and it is less 
commonly observed compared to acute myeloid leukemia (AML) [3].

The pathogenesis of ALL patients involves a complex chain of events that alter the proliferation and differentiation of hematopoietic precursor cells, chromosomal translocations, inversions, or point mutations $[1,2]$. The etiology of ALL has been under investigation for decades, but the exact cause is still unknown. Benzene, radiation, toxic gases, chemicals, hereditary diseases, benign hematologic diseases, and viruses have been researched in the etiology of ALL. Ionizing radiation and congenital genetic syndromes such as Down's, neurofibromatosis, Fanconi's anemia, and Bloom's Syndrome, all of them together explain less than $10 \%$ of cases [4,5].

Proteins, glycoproteins, and glycolipids on the surface of erythrocytes define the blood group's antigens [6]. Today, the number of serologically described blood group antigens is more than 600. Most blood group antigens are glycoproteins, and they are generally described according to their oligosaccharide and amino acid series. The antigens of $\mathrm{ABO}$ blood group are present on the extracellular membranes of erythrocytes, and these antigens are described as complex carbohydrate molecules [7]. Besides ABO blood group, $\mathrm{Rh}$ blood group is found in the system, and at least 45 independent antigens are formed [8]. Both $\mathrm{ABO}$ and $\mathrm{Rh}$ blood groups have been related to a series of diseases.

In some studies, $\mathrm{ABO}$ blood group system was shown to play a role in the development of cardiovascular, oncological, and other diseases [9]. It is known that blood group antigens join cell recognition and cell adhesion due to their specific properties. Therefore, it is likely that they play a role in the formation of tumors, metastases, and prognoses [10]. After a relationship between stomach cancer and blood group A was discovered, studies have been conducted on the possible link between blood groups and specific diseases [11]. In this study, we intended to find out whether there is a relationship between ALL and blood group types.

\section{METHOD}

The blood group types of 124 ALL patients treated in our center between February 2014 and
April 2020 were retrospectively studied. The study was approved by the local ethical committee. The ALL patients that were diagnosed by morphological findings of bone marrow aspirates and the examination of leukemic cells with flow cytometry or immunohistochemical analyses were included in the study. The data of age, gender, and blood group of healthy platelet donors were used as the control group.

IBM SPSS Statistics v21 software was used for the statistical analyses. Descriptive statistics were implemented to summarize data. Chi-square test was applied for the evaluation of categorical data and comparisons among the groups. $\mathrm{P}$ values $<0,05$ was recognized as statistically significant.

\section{RESULTS}

The ALL patients included in the study consisted of 52 females $(41.9 \%)$ and 72 males (58.1\%). The median age among entire ALL patients was 28 (range 16-80). It was 31,5 for females (range 16-80) and 26,5 for males (range 17-80). Blood group distribution of ALL patients is shown in Table 1.

The healthy individuals that constituted the control group consisted of 46 females $(22.3 \%)$ and 160 males $(77.7 \%)$. The median age for all the control group was 34 (range 2059). It was 35 (range 20-56) for females and 34 (range 20-59) for males. Blood group distribution of healthy donors is shown in Table 2.

Although the most frequently seen blood group was A, no significant difference was found between the control group and ALL patients group regarding the distribution of ABO blood groups (p:0.789). The rate of $\mathrm{Rh}$ positivity was similar in both the patient group and the control group. When both groups were sub-grouped according to gender, they did not differ between $\mathrm{ABO}$ and $\mathrm{Rh}$ distribution (Table $3)$.

Table 1: Blood group distribution in ALL patients group

\begin{tabular}{|l|l|l|l|}
\hline $\begin{array}{l}\text { Blood } \\
\text { Group }\end{array}$ & $\begin{array}{l}\text { Females } \\
\%\end{array}$ & Males (n, \%) & Total $(\mathbf{n}, \%)$ \\
\hline
\end{tabular}




\begin{tabular}{|l|l|l|l|l|l|l|}
\hline $\begin{array}{l}0 \mathrm{Rh}(- \\
)\end{array}$ & 0 & $(0 \%)$ & 3 & $(4,2 \%)$ & 3 & $(2,4 \%)$ \\
\hline $\begin{array}{l}0 \quad \mathrm{Rh} \\
(+)\end{array}$ & 15 & $(28,8 \%)$ & 23 & $(31,9 \%)$ & 38 & $(30,6 \%)$ \\
\hline $\begin{array}{l}\mathrm{A} \mathrm{Rh} \\
(-)\end{array}$ & 3 & $(5,8 \%)$ & 0 & $(0 \%)$ & 3 & $(2,4 \%)$ \\
\hline $\begin{array}{l}\mathrm{A} \mathrm{Rh} \\
(+)\end{array}$ & 19 & $(36,5 \%)$ & 27 & $(37,5 \%)$ & 46 & $(37,1 \%)$ \\
\hline $\begin{array}{l}\mathrm{AB} \mathrm{Rh} \\
(-)\end{array}$ & 2 & $(3,8 \%)$ & 2 & $(2,8 \%)$ & 4 & $(3,2 \%)$ \\
\hline $\begin{array}{l}\text { AB Rh } \\
(+)\end{array}$ & 3 & $(5,8 \%)$ & 3 & $(4,2 \%)$ & 6 & $(4,8 \%)$ \\
\hline $\begin{array}{l}\text { B Rh } \\
(-)\end{array}$ & 2 & $(3,8 \%)$ & 1 & $(0,8 \%)$ & 3 & $(2,4 \%)$ \\
\hline $\begin{array}{l}\text { B Rh } \\
(+)\end{array}$ & 8 & $(15,4 \%)$ & 13 & $(18,1 \%)$ & 21 & $(16,9 \%)$ \\
\hline Total & 52 & $(100 \%)$ & 72 & $(100 \%)$ & 124 & $(100 \%)$ \\
\hline
\end{tabular}

ALL: Acute lymphoblastic leukemia

Table 2: Blood group distribution of healthy donors

\begin{tabular}{|l|l|l|l|l|l|l|}
\hline $\begin{array}{l}\text { Blood } \\
\text { Group }\end{array}$ & \multicolumn{2}{|l|}{$\begin{array}{l}\text { Females (n, } \\
\%)\end{array}$} & \multicolumn{2}{|l|}{ Males (n, \%) } & \multicolumn{2}{|l|}{ Total (n, \%) } \\
\hline $\begin{array}{l}0 \text { Rh } \\
(-)\end{array}$ & 5 & $(10.9 \%)$ & 5 & $(3.1 \%)$ & 10 & $(4.9 \%)$ \\
\hline $\begin{array}{l}0 \text { Rh } \\
(+)\end{array}$ & 17 & $(37 \%)$ & 41 & $(25.6 \%)$ & 58 & $(28.2 \%)$ \\
\hline $\begin{array}{l}\text { A Rh } \\
(-)\end{array}$ & 5 & $(10.9 \%)$ & 2 & $(1.3 \%)$ & 7 & $(3.4 \%)$ \\
\hline $\begin{array}{l}\text { A Rh } \\
(+)\end{array}$ & 11 & $(23.9 \%)$ & 74 & $(46.3 \%)$ & 85 & $(41.3 \%)$ \\
\hline $\begin{array}{l}\text { AB } \\
\text { Rh (-) }\end{array}$ & 0 & $(0 \%)$ & 7 & $(4.4 \%)$ & 7 & $(3.4 \%)$ \\
\hline $\begin{array}{l}\text { AB } \\
\text { Rh } \\
(+)\end{array}$ & 3 & $(6.5 \%)$ & 13 & $(8.1 \%)$ & 16 & $(7.8 \%)$ \\
\hline $\begin{array}{l}\text { B Rh } \\
(-)\end{array}$ & 0 & $(0 \%)$ & 3 & $(1.9 \%)$ & 3 & $(1.5 \%)$ \\
\hline $\begin{array}{l}\text { B Rh } \\
(+)\end{array}$ & 5 & $(10.9 \%)$ & 15 & $(9.4 \%)$ & 20 & $(9.7 \%)$ \\
\hline Total & 46 & $(100 \%)$ & 160 & $(100 \%)$ & 206 & $(100 \%)$ \\
\hline
\end{tabular}

Table 3: The relationship between ALL patients and healthy donors in the control group regarding $\mathrm{ABO}$ distribution and $\mathrm{Rh}$ positivity

\begin{tabular}{|l|l|}
\hline $\begin{array}{l}\text { Parameter } \\
\text { Distributions }\end{array}$ & $\begin{array}{l}\text { ALL vs Control Group (p- } \\
\text { value) }\end{array}$ \\
\hline $\mathrm{A}, \mathrm{B}, \mathrm{AB}, \mathrm{O}$ (all) & $\mathrm{p}: 0,182$ \\
\hline $\begin{array}{l}\mathrm{A}, \quad \mathrm{B}, \quad \mathrm{AB}, \quad \mathrm{O} \\
\text { (Females) }\end{array}$ & $\mathrm{p}: 0,252$ \\
\hline $\begin{array}{l}\mathrm{A}, \quad \mathrm{B}, \quad \mathrm{AB}, \quad \mathrm{O} \\
\text { (Males) }\end{array}$ & $\mathrm{p}: 0,120$ \\
\hline Rh (all) & $\mathrm{p}: 0,480$ \\
\hline Rh (Females) & $\mathrm{p}: 0,280$ \\
\hline
\end{tabular}

\begin{tabular}{|l|l|}
\hline Rh (Males) & $\mathrm{p}: 0,580$ \\
\hline
\end{tabular}
ALL: Acute lymphoblastic leukemia

\section{DISCUSSION}

For many years, ABO blood group antigens have been suspected of having a role in the development of cancer. Since Aird et al. first reported the relationship between peptic ulcer and gastric carcinoma and $\mathrm{ABO}$ blood types, so many studies have been conducted regarding this subject [11-14]. In a prospective study consisting of a cohort of middle-aged and old Chinese males conducted by Huang et al., it was indicated that blood group B had a lower risk for overall cancer, blood groups $\mathrm{B}$ and $\mathrm{AB}$ were shown to have a lower risk for gastrointestinal cancers including stomach and colorectal cancer when compared to blood group A. However, this study also indicated higher liver cancer risk for blood group $\mathrm{AB}$ and lower bladder cancer risk for blood group $B$ [15]. These findings claim that $\mathrm{ABO}$ blood group antigens were also expressed in the epithelium cells of gastrointestinal and urinary tracts and ABO blood groups play a role in the development of epithelial cancers of gastrointestinal and urinary tracts. In studies conducted previously among the western populations, approximately $20 \%$ increased stomach cancer risk was found out for individuals with blood group A [15].

All these studies specifying solid tumors and $\mathrm{ABO}$ blood group relationship may suggest that the same association could also exist in hematological cancers, but there are limited number of studies pointed the relationship between hematological cancers and ABO blood groups. Iodis et al. reported that there was a statistically significant difference in the distribution of blood group 0 in Hodgkin lymphoma and Non-Hodgkin lymphoma [16]. In various studies, contradictory results have been reported regarding the relationship between blood groups and acute leukemia patients. Some of the studies revealed that blood group 0 was more often found in acute leukemia patients; however, other researchers reported varying results in their studies [17]. Nagy et al. showed a higher rate of blood group 0 in female acute leukemia patients [18]. Steinberg et al. did not find any difference in the distribution of 
ABO blood group in acute leukemia patients [19]. When Shirley et al. reviewed the studies previously published, they could not find any statistically significant difference in the distribution of blood group 0 in acute leukemia patients compared with the control groups [20]. MacMahon et al. could not find a relationship between $\mathrm{ABO}$ blood group distribution and acute leukemia and between $\mathrm{ABO}$ blood groups and survival of acute leukemia patients, either [21]. In a study conducted by Sadeghian et al., although there was no statistically significant relationship between $\mathrm{ABO}$ and $\mathrm{Rh}$ blood groups and acute leukemia, higher rates of blood group $B$ were found in female patients [22]. In a study conducted to reveal the distribution of $\mathrm{ABO}$ blood groups in leukemia patients in BosniaHerzegovina, equal distributions of both $\mathrm{A}$ and $\mathrm{O}$ blood groups were found among children with ALL [23].

In our study, only ALL patients were included rather than all acute leukemia patients to be more precise. Some studies are suggesting a feasible relationship between $\mathrm{ABO}$ blood groups and ALL, but this argument has not yet been justified due to the studies reporting the vice versa. When the studies including only ALL patients, as our study, were reviewed, a relationship was found between $\mathrm{AB}$ blood group and ALL in a study conducted with 293 ALL patients by Tavasolian et al. [24]. In the study conducted with 151 ALL patients by Kar et al., the distribution of blood group A was found at a higher rate in ALL patients [25]. Also, in our study, although the frequency of blood group A was found higher both in males and females, this finding did not create a statistically significant difference when it was compared to the healthy control group. Also, in our study, the rate of Rh positivity was similar between the ALL and the control group. When both groups were sub-grouped regarding gender, they were still identical regarding $\mathrm{ABO}$ and $\mathrm{Rh}$ distribution. Our study has limitations, first we were not able to investigate $\mathrm{ABO}$ and RH blood groups combined and second limitation was small sample size.

In conclusion, though there are numerous studies regarding the relationship between solid tumors and ABO blood groups, studies concerning the association between hematological malignancies and blood groups are very limited, and the results are also controversial. In our study, although the most frequently detected blood group was A, no significant difference was observed between the control group and ALL patients group relating the distribution of $\mathrm{ABO}$ and $\mathrm{Rh}$ blood groups. Our study suggests blood group frequency might be similar among ALL patients with healthy individuals. Studies directed with larger patient populations are required in this subject.

\section{Referanslar}

1-Fey MF, Buske C. ESMO Guidelines Working Group. Acute myeloblastic leukaemias in adult patients: ESMO Clinical Practice Guidelines for diagnosis, treatment and follow-up. Ann Oncol 2013;24 Suppl 6:vi138-43.

2- De Kouchkovsky I, Abdul-Hay M. Acute myeloid leukemia: a comprehensive review and 2016 update. Blood Cancer J 2016; 1; 6(7): e441 3-Surveillance, Epidemiology, and End Results Program. National Institutes of Health. Available

at https://seer.cancer.gov/statfacts/html/alyl.htm 1. Accessed: January 16, 2020.

4- Hoelzer D, Bassan R, Dombret H et al. ESMO Guidelines Committee. Acute lymphoblastic leukaemia in adult patients: ESMO Clinical Practice Guidelines for diagnosis, treatment and follow-up. Ann Oncol. 2016;27(suppl 5): 69-82. 5-. Linabery AM, Ross JA. Trends in childhood cancer incidence in the U.S. (1992-2004). Cancer. 2008; 112(2):416-32.

6- Sloan SR, Benjamin RJ, Friedmanlain DF, Webb J, Silberstein L. 2003. Transfusion Medicine. In: Nathan DG, Ginsburg D, Orkin SH, Look AT. Nathan and Oski's Hematology of Infancy and Childhood. Sixth Edition 2003, Philadelphia, Saunders 1709-56.

7- Storry JR, Olsson ML. The ABO blood group system revisited: a review and update. Immunohematology. 2009;25(2):48-59.

8- Schwarz HP, Dorner F. Karl Landsteiner and his major contributions to haematology. $\mathrm{Br} \mathrm{J}$ Haematol. 2003 May;121(4):556-65.

9- Franchini M, Favaloro EJ, Targher G, Lippi G. ABO blood group, hypercoagulability, and cardiovascular and cancer risk. Crit Rev Clin Lab Sci. 2012;49(4):137-49.

10- Weisbrod AB, Nilubol N, Weinstein LS, et al. Association of type-O blood with neuroendocrine tumors in multiple endocrine neoplasia type 1. J Clin Endocrinol Metab. 2013;98(1): E109-E14.

11. Aird I, Bentall HH, Roberts JA. A relationship between cancer of stomach and the $\mathrm{ABO}$ blood groups. $\mathrm{Br}$ Med J. 1953;1(4814):799-801.

12-Aird I, Bentall H, Mehigan JA, Roberts JA. The blood groups in relation to peptic ulceration and carcinoma of colon, rectum, breast, and bronchus; an association between the $\mathrm{ABO}$ 
groups and peptic ulceration. Br Med J. 1954; 2(4883):315-21.

13-Vogel F. Controversy in human genetics. ABO blood groups and disease. Am J Hum Genet. 1970; 22 (4):464-75.

14-Newman E, Naifeh GS, Auer JE, Buckwalter JA. Secretion of $\mathrm{ABH}$ antigens in peptic ulceration and gastric carcinoma. Br Med J. 1961; 1(5219):92-4.

15-Huang JY, Wang R, Gao YT, Yuan JM. ABO blood type and the risk of cancer - Findings from the Shanghai Cohort Study. PLoS One. 2017;12(9): e0184295.

16- Iodice S, Maisonneuve P, Botteri E, Sandri MT, Lowenfels AB. ABO blood group and cancer. European journal of cancer. 2010;46(18):3345-50.

17- Amundadottir L, Kraft P, StolzenbergSolomon RZ, Fuchs CS, Petersen GM, Arslan AA. et al. Genome-wide association study identifies variants in the ABO locus associated with susceptibility to pancreatic cancer. Nature genetics. 2009;41(9):986-90.

18- Nagy P, Jakó J, Kiss A, Tamás E, Telek B, Rak K. Sex-linked difference in blood-group distribution among patients suffering from acute leukaemias. Br J Haematol. 1981;48(3):507-8. 19-Steinberg AG, Steinfeld JL. The genetics of acute leukemia in children. Cancer. 1960;13(5):985-99.

20-Shirley R, Desai R. Association of leukemia and blood groups. Journal of Medical Genetics. 1965;2(3):189.

21- MacMahon B, Forman D. Variation in the duration of survival of patients with acute leukemia. Blood. 1957;12(8):683-93.

22-Sadeghian MH, Ebrahimzadeh S. Frequency of $\mathrm{ABO}$ and $\mathrm{Rh}$ blood groups in patients with acute leukemia. J GorganUni Med Sci. 2011; 13(1): 121-6.
23-Mustacchi P, Shonfeld EM, Lucia S. Survival in Acute Leukemia: The Influence of Blood Groups, Sex, and Age at Onset. Annals of internal medicine. 1960;52(5):1099-107.

24-Tavasolian F, Abdollahi E, Vakili M, Amini A. Relationship between ABO blood group and Acute Lymphoblastic Leukemia. Iranian Journal of Pediatric Hematology Oncology.2014; 4(1): $1-4$

25- Kar F, Andıç N, Kiraz Z. Distribution of Blood Groups in Different Types of Leukemia Patients in Eskişehir, Turkey. Turk J Life Sci. 2018; (3) 1:214-7. 